
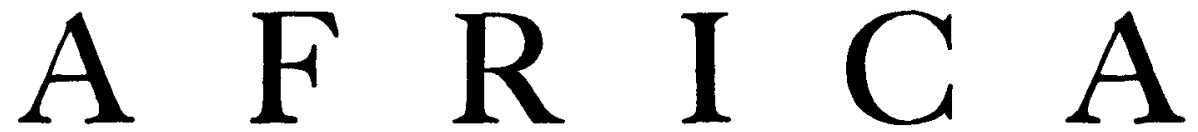

JOURNAL OF THE INTERNATIONAL AFRICAN INSTITUTE

\title{
A TRIBUTE TO DR. J. H. OLDHAM, 1874-1969
}

Administrative Director, International African Institute, 193 I-8

$\mathrm{T}$ his address at the Memorial Service for Dr. J. H. Oldham on 3 June 1969 Dr. Visser I $t^{\prime}$ Hooft, Secretary General of the World Council of Churches, referred more than once to J. H. Oldham's singular gift of 'reading the signs of the times'. This insight into the meaning and implications of events and trends, past, present, and anticipated, is what statesmen in all walks of life desire though few achieve it. In the troubled years after the founding of the International African Institute in 1926, up to the outbreak of war in 1939, the cross currents of events, policies, ideologies rocked even long-established institutions. The steady course held by the young International African Institute, and its progressive development, was due to a remarkable quartet of men: Lord Lugard, Sir Hans Visscher, Professor Malinowski, and Dr. Oldham. Between them they represented the main sources from which the Institute drew its early strength, its supporters, and its research workers: African governments, foundations, anthropologists and linguists, and missionaries with specialized knowledge of African languages and cultures.

When Dr. Oldham asked me to meet him in $1933 \mathrm{I}$ had no intention of going to Africa. My previous experience had been in India, where intensive contact with situations involving migrant labour had driven me to study anthropology under Professor Malinowski, in the hope of finding guide lines and techniques for understanding the intricate problems of Indian peasants turned factory workers. I left that lunch table in 1933 committed to putting in an application for an Institute Fellowship to study migrant labour and its effects on tribal life in Africa.

In his personal contacts with Fellows of the Institute Dr. Oldham recognized the varied motives which underlay their studies, their field-work, and their ultimate publications. With my background of India, I attached great value to three aspects of the work of the Institute which Dr. Oldham developed in subsequent interviews. The first was his emphasis on the potentialities of the African people, men, women, and children, in their traditional way of life and in their adaptation to inevitable cultural changes. The second was his firm belief, shared by all too few in those early

'Africa', the Journal of the International African Institute, is published by the Institute, but except where otherwise stated the writers of the articles are responsible for the opinions expressed. Issued quarterly. (C) International African Institute, 1970. All rights reserved. 
years, that the studies made by anthropologists could be of service to those who had to plan and carry out developments in administration, education, health, economic growth, etc. This co-operation in the field between the anthropologist and the 'practical man' was no easy or straightforward task. Dr. Oldham with his wide experience knew just how problematic the success of such co-operation could be, but that did not shake his conviction that these two sets of people were complementary to each other, and that both together could contribute to the advance of the African peoples.

Finally, Dr. Oldham believed in and demonstrated how essential were the international aspects of study and development in Africa. In the 1930 s this was no easily held conviction, but it was an inherent tenet of the Institute, and Dr. Oldham with the other members of the 'quartet' gave it whole-hearted support. The advantages of hindsight make this international emphasis in African studies very clear today, but when the quartet were patiently building up the Institute it was none too evident. In this ' reading the signs of the times' Dr. Oldham projected his conviction far into the future, and the subsequent history of the Institute has continued to justify it. Margaret Read 